\title{
PERSONAL AND SOCIAL FACTORS AFFECTING THE PREVENTIVE BEHAVIOR AMONG PATIENTS WITH TYPE II DIABETES MELLITUS IN PONOROGO, EAST JAVA, INDONESIA
}

\author{
Nur Aida Yuliana', ${ }^{1}$ (awito²), Bhisma Murti1) \\ 1)Masters Program in Public Health, Universitas Sebelas Maret \\ 2)Faculty of Social and Political Sciences, Universitas Sebelas Maret
}

\begin{abstract}
Background: Self-management of diabetes mellitus (DM)) is critical in preventing longterm complications. It includes proper medication use, diet, physical activity, blood glucose monitoring, foot care, and periodic health checkups. The purpose of this study was to examine personal and social factors affecting the preventive behavior among patients with type II DM.

Subjects and Method: A cross-sectional study was carried out at Regional Hospital in Ponorogo, East Java, Indonesia, from January to February 2020. A sample of 200 patients with type 2 DM was selected randomly. The dependent variable was preventive behavior toward type $2 \mathrm{DM}$. The independent variables were observational learning, vicarious learning, imitation, attitude, knowledge, self-efficacy, and self-management. The data were collected by questionnaire anad analyzed by a multiple logistic regression run on Stata 13 .

Results: Tertiary preventive behavior toward type 2 DM increased with good observational learning $(\mathrm{b}=1.55 ; 95 \% \mathrm{CI}=0.59$ to $2.51 ; \mathrm{p}=0.002)$, strong vicarious learning $(\mathrm{b}=1.15 ; 95 \% \mathrm{CI}=0.17$ to $2.13 ; \mathrm{p}=0.021)$, strong imitation $(\mathrm{b}=1.55 ; 95 \% \mathrm{CI}=0.58$ to 2.52 ; $\mathrm{p}=0.002)$, positive attitude $(\mathrm{b}=1.28 ; 95 \% \mathrm{CI}=0.35$ to $2.22 ; \mathrm{p}=0.007)$, good knowledge $(b=1.10 ; 95 \% C I=0.14$ to $2.06 ; p=0.024)$, strong self-efficacy $(b=1.06 ; 95 \% C I=0.11$ to 2.02; $\mathrm{p}=0.029)$, and self-management $(\mathrm{b}=2.26 ; 95 \% \mathrm{CI}=1.24$ to $3.29 ; \mathrm{p}<0.001)$.

Conclusion: Tertiary preventive behavior toward type 2 DM increases with good observational learning, strong vicarious learning, strong imitation, positive attitude, good knowledge, strong self-efficacy, and self-management.
\end{abstract}

Keywords: social cognitive theory, type 2 Diabetes Mellitus

\section{Correspondence:}

Nur Aida Yuliana. Masters Program in Public Health, Universitas Sebelas Maret. Jl. Ir. Sutami 36A, Surakarta 57126, Central Java, Indonesia. Email: Aidayuliana17@gmail.com. Mobile: +6285790767582. 